\title{
Envisioning Tax Policy for Accelerated Development in India
}

No. 190

28-Feb-2017

M. Govinda Rao and Sudhanshu Kumar

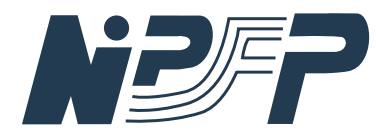

National Institute of Public Finance and Policy New Delhi 


\title{
Envisioning Tax Policy \\ for Accelerated Development in India
}

\author{
M. Govinda Rao and Sudhanshu Kumar
}

\begin{abstract}
The objective of the paper is to highlight the reforms needed in the tax system to improve the revenue productivity of the tax system to conform to the vision of accelerating economic growth and development in India. Based on the cross-country analysis of tax-GDP ratios in 98 countries, the paper estimates the extent of under-taxation in India. Assuming 8 per cent growth in GDP, the paper estimates the increase in tax-GDP ratios needed to be raised and this additional effort would provide fiscal space for much needed investments in physical infrastructure and human development. The paper goes on to identify the reforms needed to raise the revenue productivity of the tax system keeping in view the best practice approach to tax reform in India.
\end{abstract}

Keywords: Tax Policy, Tax System, Revenue Productivity, India

JEL Classification codes: E62, H2 


\section{INTRODUCTION}

With the termination of the $12^{\text {th }}$ Five Year Plan, the development strategy is likely to undergo significant changes. To guide the future developmental process in the country, the NITI Aayog, has been entrusted with the task of preparing a blueprint for the developmental strategy to accelerate developmental process of the country in an inclusive manner. In keeping with this objective, the NITI Aayog has embarked on preparing a three-year action plan beginning 2017-18, a seven-year strategy document and a 15-year vision document.

Envisioning accelerated development of the country calls for a proactive role of the government both in creating enabling environment for the markets to function, empowering the people at large to participate in the developmental process and providing social protection and safety net to the weak and vulnerable. This calls for mobilizing adequate resources for making investments in physical and social infrastructure and for providing social safety nets to the disadvantaged. This paper attempts to analyse the changes in the tax system needed to generate the required volume of resources with minimum distortions.

The principal objective of tax policy in a developing market economy is to raise revenues in an equitable manner and with minimum unintended changes in relative prices and allocation of resources. Indian tax system suffers from both low productivity and significant distortions and is in need of reform. Keeping in view the principles of efficient tax system based on developments in theory of tax reform and best practice approaches, the paper attempts to identify the reform areas to complement the vision of accelerating inclusive development in the country. Section II summarises the principles of tax policy as derived from theory and best practice approaches. Section III reviews the tax system in India and shows that the tax-GDP in the country is low by international standards. It projects the tax-GDP ratio the country should raise taking into account its average behavioural relationship with per capita GDP in a cross-country exercise. Section IV attempts to identify the problems and bring out the reform measures required to evolve a productive, efficient and an equitable tax system in the country. In Section V major conclusions of the paper are summarized.

\section{WHAT MAKES A SOUND TAX SYSTEM?}

Tax policy, and for that matter any policy, stands on the tripod of architecture, engineering and management aspects. Architecture specifies the objectives of tax reform and provides appropriate design to meet the objectives. Engineering aspect relates to the mechanics of applying the design and 
these are influenced by the nature and, nature and quality of the systems and institutions involved in tax collection. The management aspect of tax policy determines the implementation strategy and action, which depends on the political support, competence of administration, application of technology in administration and the information system. The three components are inter-dependent. A tax policy is only as good as it can be effectively administered. As Milka Cassenegra (1990) states, “... in developing countries tax administration is tax policy".

The most important objective of tax policy is to raise revenue by minimising the three costs associated with taxation, namely, the cost of collection, the compliance cost and the cost to the economy on account of distortions created. Minimising administrative and compliance costs would require the tax system to be simple and transparent. The tax policy should not be loaded with multiple objectives but designed mainly to raise revenues in an equitable manner. The best practice approach to tax policy and reforms would require the governments to broaden the base, lower the rate (BBLR) and levy a simple and transparent tax system and avoid arbitrary tax differentiation across people and economic activities (Bird and Zolt, 2008).

The major challenge is to design the tax system to incorporate fairness in its impact. Given that the distortions increase exponentially with tax rates, even when the tax is seen to be progressive, the adverse effects on economic activity and employment may negate the progressivity. Furthermore, when a tax system is designed to reduce distortions, it may contain some individual taxes that may be considered regressive. What matters is the effect of the tax system as a whole and not the impact of individual taxes on distribution of incomes (Johnson and Myles, 2011; Bird and Zolt, 2005, 2008).

The general presumption is that since the indirect taxes are regressive, the direct taxes should be designed to reduce inequalities and therefore, the traditional approach was to design highly progressive personal income tax systems and levy high rates on corporate incomes. This has, however, come into serious questioning. First, it is possible to design non-regressive consumption taxes by exempting essential unprocessed food items. Second, the effectiveness of personal income tax in reducing inequality itself is doubtful because only a small proportion of the people pay income tax in developing countries ${ }^{1}$. In most of these countries income tax is neither comprehensive nor progressive and much of the revenue comes from salary income and from withholding taxes and very little from the self-employed businesses because of poor information system and the existence of a large unorganized sector. High rates of taxes on corporate incomes, given the high mobility of capital, could drive out businesses and the tax on capital might turn out to be a tax on labour. Furthermore, progressive tax systems are not costless. They increase administrative costs, compliance costs and even more, economic distortions and the resulting of, adverse impact on economic activity on the incomes of the poor may outweigh the gains from progressivity. The experience in most countries has shown that personal income tax has not been an effec-

\footnotetext{
${ }^{1}$ In India, only 3.81 per cent of the population was tax assessee for the personal income tax during the assessment year 2014-
} 15. 
tive instrument of reducing inequalities and therefore, inferences about progressivity in the distribution of tax burden merely based on the ratio of direct and indirect taxes is misplaced (Bird and Zolt, 2005).

Empirical studies in both developed and developing countries have shown that the tax system has not been effective in redistributing incomes. The study by Pechman and Okner (1985) using alternative assumptions about the distribution of burden of individual taxes for the period 1966-1985 has shown that the US tax system is not significantly progressive. Similarly, a careful study of the Chilean tax system by Engel, Galetovec and Raddatz (1999) has shown that the tax system is in fact, moderately regressive with the Gini coefficient increasing to 0.4861 after the tax from 0.4883 before. Therefore, focus of redistribution in fiscal policy needs to shift from reducing the incomes of the rich to increasing the incomes of the poor and this implies that the focus of redistributive instrument should shift from the tax to the expenditure side of the budget. ${ }^{2}$

An important part of the tax advice given to most developing countries is to transform their consumption taxes into a broad-based Value Added Tax(VAT) on Goods and Services Tax(GST) having uniform rates. Even as the optimal theorists hold that neutrality requires levying commodity taxes in multiple rates varying inversely with compensated price elasticity of demand, the move has been towards evolving uniform tax rates for reasons of lack of information, administrative convenience and more importantly as Harberger (1990) argues, to avoid political pressures. A destination-based GST is considered neutral as it removes the taxation of inputs and capital goods. In terms of total impact, a retail sales tax levied at the last point is equivalent to VAT. However, under sales tax, if the last seller evades the tax, the revenue is completely lost whereas under VAT only the last transaction escapes the net. Given that the tax paid at each stage is only on value added at the stage, the incentive for evasion is less under the VAT. More importantly, as crediting the tax paid at the previous stage of transaction requires invoices, the tax is self-enforcing. Furthermore, seeding of permanent account numbers of income tax in VAT registration numbers can lead to significant improvement in income tax compliance and revenues.

As mentioned above, tax administration is an important leg in the tripod of tax policy. A tax policy is only as good as it is administered and therefore, it is important to keep in mind the capacity of the tax administration while designing the tax system. At the same time, it is important to constantly upgrade the administrative capacity and application of technology in tax administration. Confidence and trust between the tax administration and taxpayers is an important factor in tax compliance and therefore, the tax administration should be transparent and should consider tax payers as agents rather than adversaries. A complementary part of administration is building of proper information system, its

\footnotetext{
${ }^{2}$ As Harberger (2005. P. 13) argues, "Society is not going to bring about major changes in the income distribution by operating either on the tax side or on the expenditure side of the budget of the public sector. ....it is more realistic to think of the struggle against poverty to be a major goal". He recommends that this should be done by helping the poor to meet their basic needs and providing opportunities for advancement by ensuring access to education and healthcare to those who cannot afford it. For similar arguments see also, Bird and Zolt (2008).
} 
exchange among the tax departments and application of technology for tax administration and enforcement. Tax administration should be an independent department insulated from political pressures. Another important part of a good tax system is an efficient taxpayer service. This will help in building the trust of the taxpayers and helps in improving tax compliance.

Thus, a good tax system is one which minimises administrative cost, compliance cost and distortion cost to the economy. It should be broad based, simple and have low marginal rates and less differentiated rates. Fairness in tax policy should be judged by totality and not, individual taxes. Furthermore, tax policy has not been found to be effective in bringing about redistribution of incomes and therefore, focus should shift from reducing inequality to alleviating poverty which is better done through the expenditure side of the budget. An important component of the good tax system is a comprehensive GST. In a multilevel fiscal system it is important to coordinate tax reforms between different levels of government so that they do not work at cross purposes (Rao and Sen, 2013). A good tax system is supported by a good information system not only to enforce the tax but also to calibrate changes with full information. A hallmark of good tax administration is the adoption of technology for creating a good information system and tax payer service which will not only build confidence among the taxpayers, but also improve compliance.

\section{ANALYSIS OF TAX REVENUE IN INDIA}

\subsection{Tax Revenue Trends in India}

How does revenue productivity of the Indian tax system compare by international standards? Bird and Zolt (2003) show that in 2000, the average tax ratio for the middle income countries (per capita Income ranging from USD 1000 to USD 17000) was 22 per cent. The more recent IMF study (2011) covering 174 countries, shows that the average tax ratio for lower middle income countries (per capita GNP ranging from USD 995 to USD 3945) for the time period 1980-2009 was close to 18 per cent. In comparison, the ratio in India has been lower. After reaching 17.5 per cent in 2007-08, the ratio declined to 15.5 per cent in $2009-10$ and has been hovering around 16.2 to 16.5 per cent during the last 4 years.

We have attempted to work out the extent of under-taxation in India by estimating the tax GDP ratio that the country should raise based on cross-country relationship between tax ratio and per capita income in a regression model. We have collected data for 98 countries by combining information from both IMF (Government Finance Statistics) and OECD for the year 2010. The estimated equation was of the form:

$$
\mathrm{T} / \mathrm{Y}=\mathrm{Ln}(\mathrm{Y} / \mathrm{P})+\mathrm{Rn} / \mathrm{R}+\varepsilon
$$




\begin{tabular}{|c|c|c|c|c|c|c|c|c|c|}
\hline \multicolumn{10}{|c|}{ Table 1: Trends in tax-GDP Ratio at Union and State Levels (per cent) } \\
\hline \multirow[t]{2}{*}{ Year } & \multicolumn{3}{|c|}{ Centre } & \multicolumn{3}{|c|}{ States } & \multicolumn{3}{|c|}{ Total } \\
\hline & Direct & Indirect & Total & Direct & Indirect & Total & Direct & Indirect & Total \\
\hline $1950-60$ & 1.57 & 2.77 & 4.33 & 0.65 & 1.69 & 2.34 & 2.22 & 4.46 & 6.68 \\
\hline $1961-70$ & 1.93 & 4.49 & 6.42 & 0.44 & 2.48 & 2.92 & 2.37 & 6.97 & 9.34 \\
\hline $1971-80$ & 2.21 & 6.21 & 8.42 & 0.26 & 3.71 & 3.97 & 2.47 & 9.91 & 12.39 \\
\hline $1981-90$ & 1.96 & 7.77 & 9.74 & 0.20 & 4.79 & 4.99 & 2.17 & 12.56 & 14.73 \\
\hline 1991-2000 & 2.64 & 6.21 & 8.85 & 0.16 & 4.97 & 5.13 & 2.80 & 11.18 & 13.98 \\
\hline 2001-08 & 4.43 & 5.46 & 9.89 & 0.15 & 5.57 & 5.72 & 4.58 & 11.03 & 15.61 \\
\hline $2007-08$ & 6.26 & 5.63 & 11.89 & 0.13 & 5.43 & 5.56 & 6.39 & 11.06 & 17.45 \\
\hline 2008-09 & 5.68 & 5.07 & 10.75 & 0.14 & 5.37 & 5.51 & 5.83 & 10.43 & 16.26 \\
\hline $2009-10$ & 5.67 & 3.97 & 9.64 & 0.15 & 5.66 & 5.81 & 5.82 & 9.63 & 15.45 \\
\hline $2000-11$ & 5.63 & 4.55 & 10.19 & 0.16 & 5.99 & 6.15 & 5.79 & 10.55 & 16.34 \\
\hline $2011-12$ & 5.42 & 4.45 & 9.87 & 0.15 & 6.28 & 6.43 & 5.57 & 10.73 & 16.29 \\
\hline $2012-13$ & 5.48 & 4.77 & 10.25 & 0.14 & 6.33 & 6.47 & 5.62 & 11.10 & 16.72 \\
\hline 2013-14 & 5.54 & 4.42 & 9.96 & 0.14 & 6.44 & 6.59 & 5.69 & 10.87 & 16.55 \\
\hline 2014-15 & 5.53 & 4.36 & 9.89 & 0.14 & 6.49 & 6.64 & 5.67 & 10.85 & 16.53 \\
\hline $2008-15$ & 5.55 & 4.50 & 10.05 & 0.15 & 6.18 & 6.33 & 5.69 & 10.68 & 16.37 \\
\hline
\end{tabular}

Note: The data for 2014-15 refer to revised estimate for the Union government and budget estimate for the States.

Source: Public Finance Statistics, Ministry of Finance, Government of India (Various Years. For 2013-14 and 2014-15, Budget documents of the Union government and article on State Finances: A Study of Budgets 2014-15, Reserve Bank of India.

Where, T/Y denotes tax-GDP ratio, Y/P represents per capita GDP, and Rn/R represents the share of revenue from natural resources in total revenues. Tax revenue data is sum total of the tax revenue being generated at different levels of government(s) in a country. While Y/P represents the ability of the people to pay taxes, $\mathrm{Rn} / \mathrm{R}$ takes into account the fact that the need to raise tax revenue is lower in countries which derive substantial revenue from natural resources. It is seen that we have not included a constant term in the equation as at zero values of independent variables, the tax revenue too has to be zero.

Two alternative sets of equations are estimated one by taking per capita nominal GDP according to purchasing power parity (Table $2 \mathrm{a}$ ) and another by using simple dollar (USA) values (Table $2 \mathrm{~b}$ ). The equation with per capita nominal GDP in PPP terms is given in Table 2a:

The equation with per capita nominal GDP taken in dollar exchange rate is given in Table $2 \mathrm{~b}$.

By substituting the values of independent variables in the equation, we have estimated the average predicted values of tax-GDP ratios for countries' groups as classified by the World Bank (Table 3). The average tax-GDP ratios for different classes of countries are shown in Column 3 and the predicted average values based on the regression estimates in Table $2 \mathrm{a}$ are presented in Column 4 of Table 3. 


\begin{tabular}{|l|r|r|r|}
\hline \multicolumn{5}{|c|}{ Table 2a: Estimate for the Tax GDP ratio } \\
\hline Tax GDP ratio & Coefficient & \multicolumn{1}{|c|}{ Std. Error } & p-value \\
\hline Log (per capita income in PPP \$) & 2.642 & 0.111 & 0.000 \\
\hline $\begin{array}{l}\text { Revenue share of rent from natural resources in } \\
\text { GDP }\end{array}$ & -0.303 & 0.095 & 0.002 \\
\hline Adjusted R-squared $=0.88$ & & \\
\hline
\end{tabular}

\begin{tabular}{|l|r|r|r|}
\hline \multicolumn{4}{|c|}{ Table 2b: Estimate for the Tax GDP ratio } \\
\hline Tax GDP ratio & \multicolumn{1}{|c|}{ Coefficient } & \multicolumn{1}{l|}{ Std. Error } & p-value \\
\hline Log (per capita income in \$ terms) & 2.781 & 0.107 & 0.000 \\
\hline $\begin{array}{l}\text { Revenue share of rent from natural resources in } \\
\text { GDP }\end{array}$ & -0.261 & 0.087 & 0.003 \\
\hline Adjusted R-squared $=0.89$ & & \\
\hline
\end{tabular}

By substituting the values of independent variables in the equation using per capita GDP in PPP terms, we obtain the predicted value of tax-GDP ratio for India according to the average international behaviour. The predicted value for India based on the estimates presented in Table 2a works out to be 19.95 with the 95 per cent prediction confidence band ranging from 18.42 to 21.49 per cent. Thus, the current tax GDP ratio is much lower than even the predicted lower bound based on the international experiences as on the year 2010. Similarly, the predicted value of tax-GDP ratio derived from the equation using per capita GDP at dollar exchange rate in place of the purchasing power parity value for 2010 (using estimates in Table $2 \mathrm{~b}$ ) works out to be 18.16 per cent.

Thus, it is seen from the cross-country estimates that (i) the tax-GDP ratio increases with the level of per capita incomes; (ii) India's tax-GDP ratio of 16.5 per cent is lower than the average of Lower Middle Income group of 17.8 per cent and much lower than the predicted estimate for India from the regression at 19.95 per cent and much lower than the average predicted value for the group at 21.46 per cent; (iii) The revenue productivity of the Indian tax system has not only been low but has not shown any perceptible increase over the years, despite increases in the per capita income. In fact, it has shown a decline in the 1990s from 15.3 per cent in 1991-92 to 14 per cent in 2001-02. Thereafter, it steadily increased to 17.5 per cent in 2007-08, but declined to 15.5 per cent in 2009-10 and hovered around 16.5 per cent thereafter.

Surely, the country which aspires to accelerate its development has to substantially augment its public spending on physical infrastructure and human development. It must be noted that public spending in India has been static over the years hovering around 26-28 per cent and investments in physical and social infrastructure has been severely constrained by stagnant revenues, proliferating subsidies and 
Table 3: Average Tax GDP-ratio across income group of the countries (2010)

\begin{tabular}{|l|r|r|r|}
\hline & $\begin{array}{c}\text { Number of Countries in our } \\
\text { sample }\end{array}$ & Tax GDP ratio & Predicted Tax GDP ratio \\
\hline High income & 36 & 29.03 & 26.26 \\
\hline Upper middle & 24 & 23.84 & 23.03 \\
\hline Lower middle & 24 & 17.83 & 21.46 \\
\hline Lower income & 14 & 12.11 & 16.22 \\
\hline
\end{tabular}

transfers and limits on borrowing placed by the fiscal responsibility and budget management (FRBM). It is therefore, important that efforts must be made to increase the fiscal space by increasing the tax-GDP ratio at least to the average levels.

In order to project the tax-GDP ratio for the period up to 2030, we have taken the equation with per capita GDP with converted US dollar exchange rate (as reported in Table 2b). Although, it would be prudent to generate the forecast using estimates in Table $2 \mathrm{a}$, the choice of Table $2 \mathrm{~b}$ estimates over Table $2 \mathrm{a}$ is based on convenience in predicting the independent variable per capita income in terms of US dollar over the PPP values. Assuming that the country will grow at 7 per cent in real terms with average annual inflation of 5 per cent (i.e. a nominal growth rate of 12 per cent), unchanged exchange rate of 1 US Dollar= INR 67 and the prevailing share of natural resource income in total revenues would remain constant at 7.11 per cent, we have estimated the projected tax-GDP ratio for each of the years from 201617 to 2030-31. Accordingly, the predicted tax-GDP ratio as shown in Table 4 increases from 18.91 per cent in 2016-17 to 2.84 per cent in 2030-31.

\begin{tabular}{|r|r|}
\hline \multicolumn{2}{|c|}{ Table 4: Predicted Tax-GDP ratio for India } \\
\hline $2016-17$ & 18.91 \\
\hline $2017-18$ & 19.19 \\
\hline $2018-19$ & 19.47 \\
\hline $2019-20$ & 19.75 \\
\hline $2020-21$ & 20.03 \\
\hline $2021-22$ & 20.31 \\
\hline $2022-23$ & 20.59 \\
\hline $2023-24$ & 20.87 \\
\hline $2024-25$ & 21.15 \\
\hline $2025-26$ & 21.43 \\
\hline $2026-27$ & 21.71 \\
\hline $2027-28$ & 21.99 \\
\hline $2028-29$ & 22.27 \\
\hline $2029-30$ & 22.55 \\
\hline $2030-31$ & 22.84 \\
\hline
\end{tabular}




\subsection{What ails the Indian tax system ${ }^{3}$}

The low revenue productivity of the Indian tax system has been a matter of concern and despite several rounds of reforms the tax-GDP ratio has remained stubbornly static. The highest tax-GDP ratio at 17.5 per cent was reached in 2007-08, but it declined to 15.5 per cent in 2009-10 as the rates of excise and service taxation were reduced in response to global financial crisis. The revenues could partially recover to around 16.5 per cent in subsequent years mainly due to marginal increase in the tax-GDP ratio of the States.

The most important factor for the low revenue productivity of the Indian tax system has to be found in the narrow tax bases. There are a variety of reasons rendering the tax bases narrow and these include (i) the fragmented Constitutional assignment, (ii) wide ranging tax preferences, (iii) multiplicity of objectives assigned to tax policy resulting in complications in the tax laws, wide avenues for evasion and avoidance and large and increasing amounts held in disputes, (iv) tax abuse by multinational companies resulting in base erosion and profit shifting and $(\mathrm{v})$ poor capacity of tax administration including the information system to effectively administer and enforce the taxes.

Inability to levy a comprehensive income tax in India, in part, lies in the constitutional assignment itself. The assignment of the tax on incomes from agriculture to the States has resulted in the Union government levying tax only on non-agricultural incomes. The States do not levy the agricultural income tax except the income from plantation crops. Even the corporates making investments in agricultural sector do not have to pay the tax. There have been a number of studies estimating the potential from taxing agriculture and the more recent study by Rao and Sengupta (2011) for 2008-09 estimates the potential at 0.6 per cent of GDP. The exemption to the agricultural sector prevents the levy of comprehensive income taxation and provides easy avenue for the evasion and avoidance.

The second important reason for the narrow base of taxes is a plethora of exemptions, concessions and deductions given in direct and indirect taxes. A close look at the number of objectives pursued by the tax system is enough to understand the complications and its ineffectiveness in achieving the multiple objectives. Besides raising revenues, the tax system is required to fulfil a number of objectives such as incentivising savings, promoting exports, achieving balanced regional development, promoting investments in infrastructure, expanding employment, promoting scientific research and development, encouraging cooperatives and charitable activities. Similarly, the excise duty is supposed to provide preferential treatment to small scale industries by keeping the threshold high, promoting backward area development. Incorporation of all these objectives in tax laws creates enormous avenues for evasion and avoidance and no one can be sure how much of these objectives are achieved if at all.

Since 2006, Government of India has been publishing estimates of revenue foregone from var-

\footnotetext{
3 This section is based substantially on Rao and Rao (2005/06) and Rao (2015/16)
} 
ious tax concessions in the budget. For 2014-15, the budget estimates of the revenue foregone was at a staggering INR 5,89,285 crores. Of this, INR 3,01,688 crores was on account of customs and INR $1,84,764$ crores on account of excise duties. These are clearly overestimates due to the shortcomings in the methodology employed as revenues forgone when the customs duty is reduced to overcome domestic scarcity as well as exemptions given to imports used in the processing for re-exports are included in the estimates.

\begin{tabular}{|c|c|c|c|c|c|c|c|c|}
\hline Year & $\begin{array}{l}\text { Corpora- } \\
\text { tion Tax }\end{array}$ & $\begin{array}{c}\text { Personal } \\
\text { Income } \\
\text { Tax }\end{array}$ & $\begin{array}{c}\text { Total } \\
\text { Direct } \\
\text { Taxes } \\
\end{array}$ & $\begin{array}{c}\text { Customs } \\
\text { Duty }\end{array}$ & $\begin{array}{l}\text { Excise } \\
\text { Duty }\end{array}$ & Service Tax & $\begin{array}{c}\text { Total } \\
\text { Indirect } \\
\text { Taxes }\end{array}$ & $\begin{array}{c}\text { Total } \\
\text { tax-Centre }\end{array}$ \\
\hline 1991-1992 & 1.17 & 1.00 & 2.26 & 3.30 & 4.17 & 0.00 & 7.35 & 10.00 \\
\hline 1995-1996 & 1.34 & 1.27 & 2.74 & 2.91 & 3.28 & 0.07 & 6.31 & 9.07 \\
\hline $2001-2002$ & 1.55 & 1.36 & 2.94 & 1.71 & 3.08 & 0.14 & 4.98 & 7.94 \\
\hline $2005-2006$ & 2.74 & 1.55 & 4.30 & 1.76 & 3.01 & 0.62 & 5.62 & 9.95 \\
\hline 2006-2007 & 3.36 & 1.97 & 5.34 & 2.01 & 2.74 & 0.88 & 5.88 & 11.03 \\
\hline $2007-2008$ & 3.87 & 2.17 & 6.05 & 2.09 & 2.48 & 1.03 & 5.93 & 11.89 \\
\hline 2008-2009 & 3.79 & 1.88 & 5.68 & 1.77 & 1.93 & 0.55 & 4.51 & 10.75 \\
\hline 2009-2010 & 3.78 & 1.89 & 5.68 & 1.29 & 1.59 & 0.90 & 3.94 & 9.64 \\
\hline 2010-2011 & 3.84 & 1.79 & 5.63 & 1.74 & 1.77 & 0.91 & 4.53 & 10.19 \\
\hline 2011-2012 & 3.58 & 1.83 & 5.42 & 1.66 & 1.61 & 1.09 & 4.43 & 9.87 \\
\hline $2012-2013$ & 3.52 & 1.94 & 5.48 & 1.63 & 1.74 & 1.31 & 4.74 & 10.25 \\
\hline 2013-2014 & 3.45 & 2.08 & 5.54 & 1.51 & 1.48 & 1.35 & 4.39 & 9.96 \\
\hline 2014-2015 & 3.37 & 2.15 & 5.53 & 1.49 & 1.46 & 1.33 & 4.33 & 9.89 \\
\hline $2015-2016$ & 3.34 & 2.27 & 5.61 & 1.48 & 1.62 & 1.49 & 4.64 & 10.27 \\
\hline $\begin{array}{c}\text { Growth } \\
\text { rate: } \\
1990-91 \text { to } \\
2001-02 \\
\end{array}$ & 19.58 & 18.57 & 19.29 & 10.06 & 10.47 & 33.07 & 10.62 & 12.74 \\
\hline $\begin{array}{l}\text { Growth } \\
\text { rate: } \\
2002-03 \text { to } \\
2007-08 \\
\end{array}$ & 31.80 & 21.29 & 27.76 & 17.23 & 9.40 & 63.25 & 17.00 & 21.26 \\
\hline $\begin{array}{l}\text { Growth } \\
\text { rate: } \\
2007-08 \text { to } \\
2014-15\end{array}$ & 12.13 & 17.46 & 14.00 & 13.54 & 10.65 & 31.42 & 15.23 & 13.91 \\
\hline
\end{tabular}

Note: $\quad$ 1. Total direct taxes include revenue from other minor taxes such as estate duty and wealth tax.

2. Total taxes include Union Territory taxes also.

Source: Budget Documents, Ministry of Finance, Government of India

Nevertheless, the tax-expenditure estimates bring out a glaring shortcoming in the tax system constraining the revenue productivity. The revenue lost on account of special economic zones for 201415 was estimated at INR 20,376 crores from the corporate tax alone. The revenue cost of area based incentives for 2014-15 was estimated at INR 17,284 crores from excise duty and almost INR 8,000 crores 
in the case of corporation tax. The revenue forgone on account of tax concession to infrastructure industries works out to INR 22,230 crores. There are also customs duty reductions in the case of items like fertilizers. A close scrutiny of these tax preferences could easily result in enhancing the ratio of tax to GDP by at least one percentage point.

The analysis of Union taxes shows that the revenue from Union excise duties has been growing at a rate lower than the GDP resulting in the steady decline from 4.2 per cent in 1990-91 to 1.5 per cent in 2014-15 (R. E). Even during the 2001-02 to 2007-08, when the economy was in the high growth phase, the revenue from the tax grew at an average rate of 9.4 per cent and in the subsequent period, the average growth rate was just about 10 per cent. The low growth of excise duty has been a major constraint in improving the revenue-GDP ratio in India and the GST reform should help in improving the buoyancy of the tax.

The detailed commodity-composition of the revenues from the tax shows high commodity concentration (Table 6). In 2009-10, petroleum products alone contributed over 26 per cent of total revenues and the contribution of basic metals was 19 per cent. In contrast, the shares of revenue from textiles, minerals, chemicals and electrical goods showed a declines by varying percentage points, in part, reflecting the changing pattern of industrialization in the economy. The important point is that as the Union Excise duty is levied on manufactured products and the revenue productivity will depend on the pattern of industrialization. Hopefully, the introduction of GST will broaden the base of the tax and will improve the revenue productivity.

\begin{tabular}{|l|r|r|r|r|}
\hline \multicolumn{5}{|c|}{ Table 6: Commodity-Wise Collection of Union Excise Duties (Per Cent of Total) } \\
\hline & $1990-91$ & $2000-01$ & $2003-04$ & \multicolumn{2}{c|}{$2009-10$} \\
\hline Food Products & 4 & 4.5 & 3.2 & 1.7 \\
\hline Tobacco Products & 8.3 & 6.7 & 5.6 & 5.0 \\
\hline Minerals and Ores & 8.4 & 6.2 & 6.2 & 4.2 \\
\hline Petroleum Products & 13.9 & 32.9 & 41 & 26.1 \\
\hline Chemicals & 11.1 & 10.2 & 9.3 & 8.3 \\
\hline Plastics and articles thereof & 2.5 & 2.3 & 2.4 & 4.1 \\
\hline Rubber Products & 4.9 & 2.2 & 1.3 & 1.3 \\
\hline Leather and Wood Products & 0.6 & 0.2 & 0.1 & 0.9 \\
\hline Textiles and Garments & 10.8 & 4.8 & 3.7 & 2.9 \\
\hline Basic Metals & 9.6 & 10.4 & 11.2 & 19.0 \\
\hline Electrical and Electronic Goods & 16.1 & 8.8 & 7.8 & 11.2 \\
\hline Transport Vehicles & 8.4 & 8.9 & 6.6 & 12.3 \\
\hline Miscellaneous & 1.3 & 1.8 & 1.7 & 3.1 \\
\hline & 100 & 100 & 100 & 100.0 \\
\hline
\end{tabular}

Source: Central Board of Excise and Customs, Ministry of Finance, Government of India.

The fourth important factor eroding the base is the way in which multinational operate in the 
country. "Base erosion and profit shifting" by multinational companies is a worldwide phenomenon. Multinational companies indulge in a variety of ways to avoid taxes. Creating a web of complex subsidiaries and shifting the profits to subsidiaries located in low tax jurisdictions and taking advantage of the tax treaties is one of the common methods employed. Manipulating prices in related party transactions or what is usually called transfer pricing to reduce the tax liability is another. Although there are "arm's length pricing rules" to deal with transfer pricing issue, it is difficult to apply it in practice when intangible assets are involved and these include trade names, goodwill, and brand recognition as well as intellectual property, such as patents, copyrights, brands and trademarks and business methodologies. Multinational companies also act as intermediaries in product sales and distribution, make loans and interest payments to one another and charge fees to one another for activities such as management services, treasury services and investment services to reduce the tax liability.

Tax avoidance by multinational companies, as mentioned above, is a global phenomenon ${ }^{4}$. Overwhelming evidence of this even in developed countries like the United States of America, United Kingdom and European Union has led the OECD and, in more recent times the G-20 countries to demand the OECD to reform the international corporate tax. In September 2013, BEPS Action Plan was initiated to deal with Base Erosion and Profit Shifting system. In the meantime, the International Commission for the Reform of International Corporate Taxation (ICRICT) in its report has made a number of recommendations to deal with this pernicious practice (ICRICT, 2015).

In Indian context, there is considerable anecdotal evidence to show that the multinational companies have been indulging in abusive tax practices. Patnaik and Shah (2011) in their study showed that the effective corporation tax rate on multinational companies was significantly lower than domestic companies. Rao and Sengupta (2012), in their more detailed study using the prowess database, show that during the period 2006-2011, effective interest rate paid by the multinational companies were higher and amount of tax paid per unit of borrowing was lower. The paper also cites specific instances of the multinational companies indulging in wilful avoidance of the tax.

The problem is compounded by the fact that while the multinational companies have access to enormous resources which they use in hiring the best accountants and lawyers, the tax administrations in most developing countries is hamstrung by low resources as well as administrative capacity. The Ministry of Finance has put out the general anti-avoidance rules (GAAR), but the implementation has been postponed repeatedly. It is important to implement the GAAR soon.

\footnotetext{
${ }^{4}$ A recent study by United Food and Commercial Workers International Union estimates the assets stashed by Walmart in tax havens at US\$78 billion. It has 78 subsidiaries or branches of which more than 30 were created after 2009 . More than 90 per cent of these assets are owned by subsidiaries in Luxembourg and the Netherlands. The former, even without a single store in Luxembourg reported US\$ 1.3 billion as profits in 2010. (http://www.bloomberg.com/news/articles/2015-06-17/walmart-has-76-billion-in-overseas-tax-havens-report-says)
} 
While it is legitimate for the countries to demand a fair share of their taxes, it is also important that they should build capacity in their tax administrations to draft their laws better, have more competent staff and apply the laws more evenly. Of course, information exchange among the countries may help, but the countries should have the capability and intention to use the information better to enforce the laws. Surely, no country should expect others to draft and enforce the tax laws for them.

\subsection{Tax administration}

Tax administration is a critical element as it sets up the management of the tax system. According to Richard Bird (2004), "The best tax policy is worth little if it cannot be implemented effectively". However, the issue of tax administration is not just about its implementation. It has to do with ability to enforce the tax on the complex dealings of taxpayers, the attitude of the tax administration towards taxpayers, the taxpayers' confidence and trust with the tax administration, and clarity in laws to avoid discretion to tax administrators.

By all accounts, Indian tax administration does not evoke the confidence and trust that a modern tax administration should. There have been a number of reports on the reform of the tax administration beginning with Report of the Tax Reforms Commission (1991). The careful studies by Das-Gupta and Mukherjee (1998), Bagchi, Bird and Das-Gupta (1995), and more recently the Reports of the Tax Administration Reforms Commission (India, 2014, 2015) have dealt with various aspects of the reform of tax administration in detail. The issue is one of implementation of the reforms which requires political will rather than identification of reform areas.

The important problems of tax administration in India has to deal with are (i) lack of autonomy; (ii) low morale of tax administrators arising from low prospects of progression in the careers of administrators; (iii) organizational problems of separation of direct and indirect tax administration and lack of coordination, effective communication and information exchange between them; (iv) area-wise rather than functional divisions and lack of functional specialization including developing intelligence system; (v) poor information system and limited use of technology for tax administration; (vi) perverse incentive from setting targets to tax administrators and judging their performances based on the fulfilment of the targets; (vii) Poor capacity to forecast revenues; (viii) lack of clarity in tax laws and wide discretion to tax officials and build-up of huge amount of revenues; (ix) adversarial attitude of the tax administration towards taxpayers and essentially considering them as tax evaders rather than agents who collect the tax from the people on behalf of the tax departments. While the problems with both the organizational set up and the functioning of the tax administration are well known, there have been few attempts to address them.

One of the consequences of unclear tax laws and poor administration has been the build-up of huge tax arrears. At the end of 2013-14, the amount of tax arrears from various taxes amounted to over 
INR 5.83 lakh crores or 5.1 per cent of GDP (Table 7). Almost 86 per cent of this is held up in disputes. In fact, about 47 per cent of the arrears have accumulated in disputes up to 2 years and the arrears held in disputes up to 5 years work up to 76 per cent of the arrears.

\begin{tabular}{|l|r|r|r|r|}
\hline \multicolumn{5}{|c|}{ Table 7: Tax Arrears in 2013-14 } \\
\hline & $\begin{array}{l}\text { Held in Disputes } \\
\text { INR Crores }\end{array}$ & $\begin{array}{c}\text { Not Under } \\
\text { Dispute } \\
\text { INR Crores }\end{array}$ & $\begin{array}{c}\text { Total } \\
\text { INR Crores }\end{array}$ & Per cent of Total \\
\hline Corporation Tax & 150802 & 41211 & 192013 & 32.92 \\
\hline Non-Corporate Income Tax & 259721 & 23985 & 283706 & 48.63 \\
\hline Taxes on Income and Expenditure & 410523 & 65196 & 475719 & 81.55 \\
\hline Customs & 9758 & 4686 & 14444 & 2.48 \\
\hline Union Excise Duties & 41817 & 7978 & 49795 & 8.54 \\
\hline Service Tax & 41245 & 2143 & 43388 & 7.44 \\
\hline Total-Taxes on Commodities and & 97821 & 14807 & 112628 & 19.31 \\
\hline Total & 503344 & 80003 & 583347 & 100.00 \\
\hline
\end{tabular}

Source: Report of the Comptroller and Auditor General - Revenue 2013-14.

An important innovation, however, has been the creation of large taxpayers units which have helped to coordinate the functioning of CBDT and CBEC and has helped to reduce the compliance cost for large taxpayers. Another important reform has been the requirement for electronic filing of the returns and payment of refunds directly to the accounts of the taxpayers. These are only small initiatives, and by and large the tax administration does not invoke much confidence among the taxpayers to improve the voluntary tax compliance.

As mentioned earlier, professionalising the administration is important for building the confidence of the taxpayers with the tax department. Some of the initiatives required for the purpose include organization of the department on functional lines to achieve functional specialization, improvement in the information system and the capacity to undertake data mining and improvement in intelligence networks. The analysis shows that in 2012-13, the number of non-corporate taxpayers were just about 3.7 million which is less than 3.4 per cent of the population. Over 75 per cent of them had taxable incomes of less than INR 2 lakhs ${ }^{5}$. The assesses with more than INR 10 lakhs income numbered just about 6.6 lakhs which implies a very poor coverage of the tax. The number of tax payers with more than INR 1 crore reported income was just about 42,800 .

\section{THE WAY FORWARD}

Increasing revenue productivity of the tax system to raise the tax ratio envisaged for development underlines the need for the reform of both direct and indirect tax at Central as well as State levels. Increase in revenue productivity in the least distortionary manner requires expansion in the tax base, ra${ }^{5}$ Report No. 10 of 2014 (Direct Taxes), Comptroller and Auditor General, Government of India. 
tionalization of rates to levy the tax at reasonable rates, simplifying the tax system and reforms of tax administration. Some of these reforms can be taken up immediately whereas some others can be carried out only in the medium and long term. While some of the reforms are not difficult, others are not easy to carry through and in respect of some others the challenges of carrying them out are formidable. The government will have to evolve a clear strategy of carrying out those reforms that can be done without difficulty and plan to implement more difficult reforms in the medium term and work towards implementing the reforms with formidable challenges over a period of time. As emphasised by Johnson and Myles (2011, p. 323), "In the real world, proposals for tax reform are constrained by politics - those who lose from tax reforms tend to be vengeful while those who gain from them tend to be ungrateful. This can lead in tax policy, perhaps more than in any other areas of public policy, to a 'tyranny of the status quo.' There is always a tension between what is economically desirable and what is politically practical."

The most formidable task in evolving a comprehensive income tax in India, as pointed out earlier is the fractured assignment system. While it may not be easy to integrate income from agricultural and non-agricultural sectors, the practical solution may be to enter into an agreement with the States and levy the tax according to applicable rates on the income declared as agricultural incomes after allowing deductions for crop insurance premiums while computing the agricultural incomes and distribute the proceeds to the States when the income originates. This, however, is not going to be easy and would face wild political storm, but nevertheless should be in the reform agenda for the medium term. However, ways and means have to be found to tax the incomes from corporates involved in farm activities and mechanism to provide a check against wrongly declaring non-farm incomes as agricultural incomes to evade the tax.

The first discussion paper on direct taxes code was a well thought out document and many of the suggestions contained in them particularly those relating to grandfathering the tax exemptions and concessions merit consideration to broaden the base, increase revenue productivity and to reduce unintended distortions in resource allocation. It is also important to work on a time-bound plan to effectively apply the general anti-avoidance rules on the multinational companies and to develop the capacity to administer it, a special cell may be created and a time-bound plan for building capacity is taken up. Indeed, there is a need to overhaul the administrative framework to enable functional specialization and coordination among various tax departments including sharing of information. However, the transition is not likely to be easy and in the short term, it would be advisable to create specialised agencies like the one for administering GAAR and finally effect proper administrative divisions into various functionally specialised groups from the prevailing region-based divisions. It is important that the reform process is initiated to simplify and rationalise the tax system with a view to broaden the base, simplify the tax by weeding out various tax preferences and strengthen the information system technology assisted enforcement. 
The major item in the reform agenda comprises of the introduction of GST at Union and State levels. The $122^{\text {nd }}$ Constitutional amendment paves the way for its implementation and the recently established GST Council will deliberate on the structure and operational aspects. However, considerable work remains to be done. The Central and State governments will have to expeditiously pass the required legislations. The agreed rate structure with four rates in addition to a low rate, exemptions and cess on sumptuary items creates a fairly complicated structure. The exclusion of alcohol and more importantly, petroleum products and real estate transactions erodes benefits of a broad base tax substantially. There is an impasse in finalising administrative arrangements. The Central tax administration does not want to cede the power to administer service taxes to states and this is not agreed to by the latter. The state tax administrations do not want Central government to administer the GST. There are a number of issues yet to be negotiated and settled and that includes the list of exempted items, items going into each rate category, the place of supply rules particularly in respect of taxes on services with inter-state span. The capacity of tax administrators and taxpayers is another important task. It is also important that central and state governments should create taxpayer services unit to ensure smooth transition.

The original proposal for the introduction of GST was made way back in 2008 according to which the tax was supposed to have been implemented in April 2010 which was continuously postponed and the latest target set is April 2017. A realistic assessment also shows that the structure and operational details of GST emerging from the compromise agreement reached in the GST Council will be far from being flawless. There is no doubt that the introduction of GST replacing a plethora of Union and State indirect taxes is an important reform. This is expected to improve the ease of doing businesses, enhance efficiency in the supply chain by obviating the need to have branch offices (created to avoid the inter-states sales tax), reduce transaction costs by ensuring seamless trade in commodities and services across the country and improve export competitiveness by providing comprehensive relief from domestic taxes. Indeed, the extent to which these can be accomplished will depend upon the ultimate structure and operational details that will emerge. With the structure of the tax agreed upon and with several compromises that will be made in the course of finalising various aspects of structure and operational details, it would be premature to characterise the reform as "game changer". It is important to view the GST implementation as a "work in progress" and the next stage of consumption tax reform and build on it to improve the system in the future. Considering the volume of work involved and the negotiations to be done, the government should aim at rolling out the reform anytime between June and September, 2017.

The tax system for accelerating economic growth should not only have high revenue productivity but also should minimise distortions. The rationale for having broad bases and low rates of taxes is essentially to avoid distortions as distortions rise exponentially with the rate of tax. That is also the reason for replacing a plethora of cascading type indirect taxes with the GST. With the passage of time, hopefully the presently excluded items of consumption from the base of GST such as petroleum prod- 
ucts will be brought into the tax net. It is also important to reduce the rates of stamp duty to a maximum of 4 per cent to formalise transactions in land and houses which is presently one of the major sources of tax black incomes.

An important characteristic of a good tax system is that it should promote formalization of the economy and prevent informal forms of transactions. A tax on commodity transactions and security transactions, even when levied at low rates, significantly increases the transaction costs. These taxes constrain the development of forward markets in commodities and the securities markets. In fact, the budgeted revenue from securities transactions tax was INR 7,398 crores and the amount from commodities transaction tax is less than INR 300 crores. However, the cost on the economy by these taxes is manifold.

The Commodities Transaction Tax (CTT) as imposed in the budget of 2013 at the rate of $0.01 \%$ on the mistaken notion that derivatives' trading in commodities is akin to trading in securities. Securities are instruments to raise capital for investment and investors gain or lose depending on their price movements. In contrast, the function of commodity futures is hedging against the price risks for relevant physical commodities. They merely reduce unforeseen economic losses due to price fluctuations and do not yield profits as such. In fact, the major function of commodities derivatives market is price discovery. Unlike the spot price for the securities, the prices are established in hundreds of mandis and delivery centres and it results in stabilizing prices. Due to the CTT, the cost of trading is estimated to have increased by 300 per cent which has resulted in the loss in trading volume to the tune of at least 6070 per cent and migration of businesses to offshore centres such as Dubai and Singapore (Seeger, 2013). A forward looking tax policy should promote the development of markets rather than constraining them.

\section{CONCLUDING REMARKS}

Taxes matter for the government, businesses and common people alike. Governments have to collect them to provide public services. They impact the profitability of businesses. People are concerned about parting with their hard-earned money for the services they cannot clearly see and perceive. For the point of view of the economy, tax policy is an important factor in determining the business climate.

The paper argues that the best practice approach to tax policy and reform is to broaden the base, reduce the rates and their differentiation and evolve a simple and transparent system. Loading the tax policy with too many objectives complicates the tax system. The objective of reform should be to reduce the administrative, compliance and distortion costs. Thus the major reform agenda for the government should be to phase out the tax preferences to evolve a simple tax system. 
Indian tax system is characterized by low revenue productivity and stagnancy in the tax ratio. The paper has attempted to identify the reasons for the low revenue productivity of the tax system. The Constitutional assignment has constrained the levy of comprehensive income taxation. Although, it is possible to coordinate the levy between the Union and the States, political difficulties have constrained this. Narrow tax bases of both direct and indirect taxes are also the consequences of wide ranging exemptions, concessions and deductions given to pursue a variety of objectives though tax policy. Pursuit of several objectives, while their effectiveness in achieving the desired objectives are doubtful, have narrowed the bases, reduced revenue productivity and have complicated the tax system resulting in high compliance costs and distortions in resource allocation. Lack of clarity in tax laws and huge building of tax arrears, an overwhelming proportion of which is stuck in tax disputes is another problem. The paper brings out the problem of base erosion and profit shifting by multinationals and the organizational and functional problems with tax administration and the need to build capacity and professionalism in administering the tax including the building and the application of information system and technology.

The paper underlines the need for reforming both direct and indirect tax systems not only to increase the revenue productivity but also to improve the business climate in the country. The replacement of a plethora of indirect taxes with the GST is an important reform. However, the structure and operational difficulties will be decided on the basis of the compromise between the Union and the States on the one hand and among the States on the other, the resulting structure will be far from being "flawless". It is therefore, important to peg the expectation at a realistic level. It is also important to realize that the proposed structure has some shortcomings which can be corrected only over a period of time. Therefore, the reform should be considered as a work in progress and the expectation from the tax should be realistic. As regards, the reform of direct taxes is concerned, although the Finance Minister has indicated that the implementation of Direct Taxes Code will not be in the agenda, the various reforms to simplify the law, phase out the tax preferences to broaden the base and the preparatory measures needed to implement the General Anti Avoidance Role (GAAR) should be taken up. The reforms relating to tax administration to professionalise the administration and make it taxpayer friendly also needs to be pursued with vigour to improve the administrative efficiency and compliance. 


\section{REFERENCES}

Bagchi, Amaresh, Richard Bird and Arindam Das-Gupta. 1995. An Economic Approach to Tax Administration Reform, Discussion Paper No. 3. International Centre for Tax Studies, University of Torinto Faculty of Management.

Bird, Richard M. 2004. Administrative Dimensions of Tax Reform, Asia-Pacific Tax Bulletin; 10(3): 13450 .

and Eric Zolt. 2005. Redistribution via taxation: The Limited Role of the Personal Income Tax in Developing Countries, UCLA Law Review, 52(6): 1627-95.

Das-Gupta, Arindam. 2002. Central Tax and Administration Reform in the 1990s: An Assessment, in M. Govinda Rao (ed), Development, Poverty and Fiscal Policy: Decentralization of Institutions, New Delhi, Oxford University Press: 139-173.

, and Dilip Mookherjee. 1998. Incentives and Institutional Reform in Tax Enforcement, New Delhi: Oxford University Press.

Engel, Eduardo M. R. A., Alexander Galetovic and Claudio E. Raddatz. 1999. Taxes and Income Distribution in Chile: Some Unpleasant Redistributive Arithmetic, Journal of Development Studies, 59: 155-92.

Harberger Arnold, C. 1990. "Principles of taxation applied to developing countries: What have we learned?" in Michael Boskin and Charles E. McLure, Jr. (eds), World Tax reform: Case Studies of Developed and Developing Countries, San Francisco; ICS Press; 25-46.

2003. Reflections on Distributional Considerations and the Public Finances, Paper prepared for a course on "Practical Issues of Tax Policy in Developing Countries, The World Bank.

ICRICT. 2015. Declaration of the Independent Commission for the Reform of International Corporate Taxation, Independent Commission for the Reform of International Corporation: New York.

India. 2014, 2015. Report of the Tax Administration Reforms Commission, (Chairman: Parthasarathy Shome), Ministry of Finance, Government of India.

IMF. 2011. Revenue Mobilization in Developing Countries, International Monetary Fund.

Johnson Paul and Gareth Myles. 2011. The Mirrless Review, Fiscal Studies, 32(3): 319-329.

Milka Casanegra de Jantscher. 1990. Administering a VAT, M. Gills, C. S, Shoup and G. P. Sikat (eds) Value added taxation in developing Countries, World Bank.

Patnaik, Ila and Ajay Shah. 2011. Do Multinationals Pay Lower Taxes? (mimeo).

Pechman, Joseph A. and Benjamin A. Okner. 1974. Who Bears the Tax Burden? Washington D.C., The Brookings Institution.

Rao, Govinda M. 2015/16. Tyranny of Status Quo: The Challenges of Reforming the Indian Tax System, India Policy Forum, 12: 47-103.

, and R. Kavita Rao. 2005/6. Trends and Issues in tax Policy and Reform in India, India Policy

Forum, 2: 55-122. 
, and Tapas K. Sen. 2013. Federalism and Reform in India, in Stephen Howes and M. Govinda Rao (eds), Federal Reform Strategies: Lessons from Asia and Australia, New Delhi: Oxford University Press.

Rao, Kavita R. and D. P. Sengupta. 2014. Action Plan on Base Erosion and Profit Shifting: An Indian Perspective, NIPFP Working paper 2014-133.

, 2012. Direct Taxes Code and Taxation of Agricultural Income, Economic and Political Weekly, 47(15): 51-60, April 14, 2012.

Seeger, Charles. India's Commodity Transaction Tax: Economic Consequences and International Lessons Learned, Financial Markets International Inc. 


\section{MORE BY THE AUTHORS}

- M. Govinda Rao. 2013. Property Tax System in India: Problems and Prospects of Reform.WP No. II 4 (January)

- Sudhanshu Kumar and R. Kavita Rao. 2015. Minimising Selection Failure and Measuring Tax Gap:An Empirical Model, WP No. I50 (May)

\author{
M. Govinda Rao, is Emeritus \\ Professor, NIPFP \\ Email: mgovinda.rao@nipfp. \\ org.in

\section{Sudhanshu Kumar, is Assistant Professor, NIPFP Email: sudhanshu.kumar@ nipfp.org.in}

\section{MORE INTHE SERIES}

- Ila Patnaik, Joshua Felman and Ajay Shah. 2017. An Exchange Market Pressure Measure for Cross-Country Analysis.WP No. 189 (February).

- Sudipto Mundle. 2017. Employment Education and the State. WP No. 188 (February)

- Sudipto Mundle. 2017. Beyond Catch up Some Speculations About the Next Twenty Five. WP No. 187 (January).

National Institute of Public Finance and Policy,

18/2, Satsang Vihar Marg, Special Institutional Area (Near JNU),

New Delhi I 10067

Tel. No. 26569303, 26569780, 26569784

Fax: 9 I- I I-26852548

www.nipfp.org.in 